\title{
Fordításoktatási szakmai nap
}

\author{
(Károli Gáspár Református Egyetem, \\ online konferencia, 2021. január 28.) \\ Szentirmay Piroska \\ E-mail: szentirmay.piroska@gmail.com
}

Hagyományosan január végén tartotta a Károli Gáspár Református Egyetem BTK Angol Nyelvészeti Tanszék fordítástudományi kutatócsoportja a fordításoktatási szakmai napját, melyet az aktuális járványhelyzethez alkalmazkodva rövidebben, online formában szervezett meg. A „Forditáselméleti kutatások igénye és alkalmazása a gyakorlatban az 1990-es évektöl napjainkig” címü konferenciát nagy érdeklődés kísérte, a 100 fö részvételével tervezett eseményre a férőhelyek már az elözetes regisztráció során beteltek. A szakmai nap előadói között nemcsak a Károli Gáspár Református Egyetem oktatói, hanem a fordítástudomány széles körben ismert, kiemelkedő képviselői, valamint a fordítás kapcsán az üzleti életben érintett szakemberek is elöadást tartottak.

A szakmai napot, a Károli Gáspár Református Egyetem Bölcsészettudományi Karának képviseletében, Horváth Géza, a kar dékánja nyitotta meg, aki hangsúlyozta, hogy az Egyetem életében fontos szerepet kap a fordítástudomány, az interkulturalitás, ami megmutatkozik a KRE képzési programjaiban, kutatásai területeiben, publikációiban.

A szakmai nap megnyitását követően az első előadó Heltai Pál, az ELTE Fordítástudományi Doktori Programjának oktatója volt. A fordításelméleti kutatási témák változása az 1990-es évektől napjainkig címü előadásában vázlatosan mutatta be, mi is jellemezte a fordítástudományt 1990 elött, majd részletesebben tért ki azokra a területekre, melyek napjainkig a kutatási trendeket jellemzik. A kezdeti irodalomtudományi megközelítés a bibliafordítási gyakorlatra és jellemzően a müfordításra épült. A nyelvtudomány fejlődésével csökkent a fordításról való gondolkodásban az irodalomtudomány dominanciája. További fordulatot jelentett a kulturális, pragmatikai, funkcionális és szövegnyelvészeti szempontok térnyerése. Ez tükröződött a fordítóképzésben is, hiszen ezen a területen az irodalmi szövegekkel szemben szembetünő mértékben nőtt meg az érdeklődés a szakfordítások iránt. A fordítástudomány megszületésének pillanatában, Holmes 1972-es előadá-

Hivatkozás: Szentirmay P. 2021. Fordításoktatási szakmai nap. (Károli Gáspár Református Egyetem, online konferencia, 2021. január 28.) Fordítástudomány 23. évf. 1. szám. 107-111. DOI: https://doi.org/10.35924/fordtud.23.1.8 
sában már egy szerteágazó diszciplína képét adta, mely az elkövetkezendőkben felmerülö igények szerint nyitott volt a jelentős fejlődésnek induló társtudományok módszereinek átvételére.

A 90-es évektől a változások nemcsak az elméleti gondolkodást, hanem a technikai változásokkal szoros összefüggésben a módszertant és a vizsgálatok hatókörét is érintették. A kutatások kiterjedtek új vagy korábban kevésbé kutatott területekre, így a határok kitolódásával új határterületek is kialakultak. A fordító személyének, a munkakörülményeknek, a fordításnak, mint társadalmilag meghatározott folyamatnak a vizsgálata egyfajta szociológiai fordulatként értékelhető a fordítástudomány történetében, de azt a kérdést is magával hozza, hogy valóban ez lenne-e a fordítástudomány központi témája. Tagadhatatlan, hogy a vizsgálati határok kitágulása kockázatokat is hordoz magában, egyre több az elágazás, a széttagoltság, ami terminológiai problémákat is előtérbe helyez. Ezek a problémák több módszer együttes alkalmazásával orvosolhatók. Az előadás konklúziója jövőbe mutatóan állapította meg, hogy az új irányzatoknak mindig van létjogosultságuk a kockázatok ellenére is, bár a „régi” témák még mindig nem merültek ki.

Az első előadáshoz szorosan kapcsolódva a második előadó, Gulyás Adrienn a Károli Gáspár Református Egyetem egyetemi docense oktatóként kívülröl, müfordítóként belülről, a szakma oldaláról mutatta be, hogy milyen kutatási területek és témák aktuálisak ma a műfordításban.

A müfordítás elsősorban a müvészi szövegeket tanulmányozza és az irodalomtudománnyal együttmüködésben foglalkozik a paratextusokkal, a narratológiával, a recepciókutatással, az újrafordításokkal és a fordítói trendekkel, kánonokkal és nem utolsósorban a müfordítói, szerkesztői trendek változásaival. Hagyományos társtudománya a nyelvészet, melynek segítségével a prozódiai kötöttségeket kutatja a prózafordításban, továbbá az aspektusok, a többletjelentések megjelenését, a humor lexikai megnyilvánulásait a fordításban. A müfordítások vizsgálatában sem elhanyagolható a korpusznyelvészeti módszerek, ill. a CAT-es eszközök alkalmazása. Az oktathatósággal kapcsolatosan nem csak az a kérdés, hogy oktatható-e egyáltalán a müfordítás, hanem az is, hogy milyen elméleti és gyakorlati alapjai vannak, a kreativitás mennyiben érvényesül a gépiességgel szemben a fordítási piacon, és hogy hogyan változtak a müfordítói kompetenciák. A müfordítás szociológiai megközelítésben a piaci kérdéseket is érintve vizsgálja, hogy milyen az a társadalmi közeg, amelyben a müfordítások megszületnek, hogyan épül a kiadók, a fordítók, a szerzők szakmai presztízse a müfordításokon keresztül. Ehhez a területhez szorosan illeszkedik a müfordítás kultúrpolitikai megközelítése: cenzúra, öncenzúra, fordításpolitika és fordítástámogatás és ezek hatásai a könyvkiadásra. Progresszívebb interdiszciplináris kapcsolat a műfordítás és a színháztudomány kapcsolata, mely érinti a müfordítás színházi megrendeléseit, illeszkedését a rendezői igényekhez, a színpad összetett jelrendszeréhez. Az előadást záró utolsó párosítás, a műfordítás gender alapú megközelítése azt vizsgálja, hogy a fordító, ill. a mü valamelyik karakterének gendere miként érvényesül a fordított szövegben, hiszen a fordítások sokszor erősítenek fel nemi sztereotípiákat. 
A harmadik előadásban Fabiny Tibor professzor, szintén a Károli Gáspár Református Egyetem képviseletében, a bibliai fogalmak szerepéröl beszélt különféle magyar és idegennyelvi fordításokban.

A Biblia olvasásához és fordításához elengedhetetlen megfelelő szintű teológiai háttértudás, ezért a Szentírás fordítása és olvasása tudományként is megközelíthető és összehasonlító bibliaolvasás-tudománynak nevezhető. A Biblia újrafordítása még napjainkban is élénk vitákat vált ki, a különböző felekezetek különböző bibliafordításokat olvasnak. A 20. században készült új bibliafordítások előnyöket és hátrányokat is hordoznak magukban, hiszen a nyelv változásának követése az értelmezést is elősegíti, azonban hátránya a már ismert bibliai fogalmak, szövegrészek destabilizálása.

Ezeknek a kérdéseknek a tanulmányozására alakult meg 1993-ban a Hermeneutikai Kutatóközpont a Károli Gáspár Református Egyetemen. A kutatóközpont konferenciák szervezésével, szakirodalmi publikációk gondozásával is foglalkozik. Az idei év során zárja majd le hároméves Egyesített bibliaolvasó projektjét, melynek köszönhetően a különböző szövegváltozatok mind vertikálisan, mind horizontálisan összehasonlíthatóvá válnak az érdeklődők számára. A kutatómunka része a bibliafordítások digitalizálása, párhuzamos korpuszok építése, honlap indítása, idegennyelvü bibliaolvasó alkalmazások megalkotása is. A bibliaolvasások összehasonlításának alapja többek között az olvasói reakció szerinti megközelítés, valamint a Biblia, mint intertextuális szöveg vizsgálata, a Biblia régi szövegeinek időről-időre történő aktualizálása, hogy hogyan nyer a régi szöveg új jelentést az újabb és újabb fordításokban.

Az előadás három konkrét példával zárult olyan lexikai elemek bemutatásával, melyeket a különböző bibliafordításokban más-más lexikai megfelelővel fordítottak. Ezek a magyar fordítási megoldások aztán összehasonlíthatók további nyelvek, pl. angol vagy német bibliafordítások megoldásaival. Az összehasonlító, komparatív olvasásnak nyelvi és teológiai tanulságai is vannak, ezért jelent a Biblia olvasása tudományt, müvészetet és teológiai tevékenységet is.

Tönkő Vera, a Park Kiadó szerkesztője, A szerkesztési irányelvek és gyakorlat változása címmel tartott elöadásában összefoglalta több mint két évtizedes szerkesztői pályafutásának tapasztalatait.

A rendszerváltás után a könyvpiac átalakult, manapság a kiadóknak más természetü problémákkal kell megküzdeniük, ami nem kedvez a minőségi munkavégzésnek. A legnagyobb könyvsikerek a márkanévvé vált szerzőkhöz köthetők, akiknek megtartása a kiadók számára komoly anyagi megterhelést jelent. A kiadóknak mérlegelniük kell, hagyják-e, hogy ezek a szerzők határozzák meg üzletpolitikájukat, vagy vállalják a költséges értékmentést és értékteremtést. Napjaink legvesztesebb múfaja a szépirodalom és a komoly tudományos ismeretterjesztés.

Az európai szerzők közül azok tudnak Magyarországon leginkább megjelenni, akiknek hazájában megbízható fordítástámogató-programok müködnek, mert a magyar kiadók nehezen tudják finanszírozni a minőségi fordítói munkát. 
Az új digitális technológiák is gyökeresen megváltoztatták a könyvek terjesztésének és népszerűsítésének módját. A könyvkiadás egyik legnagyobb szellemi kihívása az internetet elöntő megkérdöjelezhető tartalom és az, hogy a profi szerkesztők munkáját a szerzők is egyre kevésbé tartják fontosnak. Természetesen kérdés, szabad-e belekényszeríti egy szöveget az éppen érvényes esztétikai kánonba, vagy engedni, hogy a közízlés által elfogadott anomáliák részesüljenek előnyben? De vajon hol húzódnak a határok: meddig védheti a szerző vagy a fordító a szövegét, a szerkesztő a saját álláspontját? Kinek a felelössége, ha a fordító képességeit meghaladó munkát vállal, ha a kiadó nem a megfelelő szerkesztőt bízza meg a munkával? Ki vállalja a felelősséget a fordításért? Képes-e egy jó szerkesztő rossz fordításból jó szöveget varázsolni?

Urbán Miklós, Senior Solutions Architect, a RWS Moravia képviseletében A gépi forditás, posztediting és mindemögött az ember címmel tartott elöadást arról, hogy az utószerkesztés kutatása hogyan segíti a gyakorlatot, a sztenderdizációt, mi az a humán tudás, amire még szükség van a gépi fordítást követően. A gépi fordítás térnyerése mögött a globalizáció, a tartalmi volumen megnövekedése húzódik meg, továbbá hatékonyabb büdzséfelhasználásra ad lehetőséget, amikor elsődleges cél a költségtudatosság és a minél nagyobb vásárlóerő elérése. A piac nyelvi diverzitása miatt és figyelembe véve az egy-egy piac gazdaságosságát befolyásoló szempontokat a cégek gondosan megválogatják, mely nyelvekre, milyen tartalmakat fordítanak. Ebben a rendszerben sajnos a magyar nyelv soha nem állt előkelő helyen. Az elmúlt években pedig több világcég is hátrébb sorolta, így relatíve kevés tartalmat fordítanak magyarra. Sajnos ehhez az is hozzájárul, hogy technológiailag a gépi fordítás nem tudja olyan mértékben támogatni a nyelvünket, mint más nyelveket. A magyar nyelv jellemzően a gépi fordítás minőségét összehasonlító rangsorok vége felé jelenik meg. A közhiedelemmel ellentétben a költségtudatosság nem jár együtt a gyenge minőséggel, adott tartalmak adott minőségi szintet igényelnek.

A fordítási munkafolyamat és ezzel együtt a minőségi szint kiválasztása a szöveg felhasználási céljától függ. A gépi fordítással támogatott munkafolyamatok esetén a nyers fordítás poszteditálási környezetbe kerül, amelyben humán fordítók javítják azt fel megfelelő minőségü kész fordítássá. A legfontosabb kérdés az, hogyan lehet a kívánt minőséget biztosítani, és ez hogyan alakítja majd az árazást és a költséghatékonyságot. A fordítás minősége szubjektív dolognak tűnik, de a gépi fordítás minőségének számszerü mérésére már léteznek sztenderd hibatipológiai rendszerek, amelyek a pontosság és gördülékenység kategóriáiba rendezik a hibatípusokat és súlyozza a hibákat. Több munka árán jobb minőséget lehet elérni, de az üzleti életben a költséghatékonyság szempontjából ez nem cél. A fordítóknak tehát arra kell felkészülniük, hogy nem minden esetben a tökéletes fordítás a cél, hanem a megrendelő elvárási szintjének teljesítése. A nyelvi szakembereknek képesnek kell lenniük alkalmazkodni mind a forrás minőségéhez, mind a célminőséghez. Ezeket a minőségi elvárásokat pontosan kell ismerniük, mert a túlzott szerkesztés (over-editing) nem hatékony, az alulszerkesztettség (under-editing) 
nem ad megfelelő minőséget. A gépi fordítás térnyerésével a fordítás minősége semmiképpen nem definiálható abszolút fogalomként, hanem relatívan abszolút fogalommá válik, mivel számokkal mérhetőnek kell lennie, hiszen a poszteditálás révén a szövegminőségben elért változás leképezhető a sebességre és az árazásra.

A konferencia zárásaként Klaudy Kinga, egyetemi tanár, az ELTE NYDI Fordítástudományi Doktori Programjának vezetője tartott előadást a fordításelméleti kutatások igényéről. A Fordító- és Tolmácsképző Tanszék 118 hallgatójának a 2020-2021-es tanév végén írt fordításelméleti záróvizsga dolgozata adta a spontán felmérés alapját. A vizsgafeladatok a korábbi szemeszterekhez képest új kérdéseket is tartalmaztak, amelyeknek az volt a célja, hogy feltárja, mennyiben tartották a hallgatók hasznosnak vagy fölöslegesnek a fordításelméleti elöadásokat, kaptak-e választ valamelyik fordítással kapcsolatos korábbi kérdésükre az előadásokból.

A hallgatói véleményekből intuitív becslés alapján kitünt, hogy a válaszokban használt leggyakoribb szó a „reália” volt, tehát ez nagyon megragadta a hallgatók érdeklődését. Nagy valószínüséggel ez közvetlenül kapcsolatba hozható azzal, hogy a legtöbb hallgatónak a Szociolingvisztika és fordítástudomány címü előadás tetszett a legjobban nemcsak a reáliák, de a jó példák miatt is. A visszajelzések alapján a legtöbbet a szövegnyelvészeti előadásból tanultak, ezen belül is annak második részéből, ahol a szerkesztés elötti és szerkesztés utáni példák alapján konkrét tanácsok is elhangzottak.

Mivel a vizsga online zajlott és a diákok elektronikus formában küldték be válaszaikat, a dolgozatok alkalmasak voltak gépileg automatikusan elemezhető, 11079 szavas, 84477 betühelyes korpusz építésére a Sketch Engine programban. Az elemzések alapján beigazolódott, hogy a leggyakrabban használt kulcsszó valóban a „reália” volt és a szövegnyelvészeti előadásra utaló „szövegszintü” kulcsszó is előkelő helyet foglalt el a gyakorisági sorrendben. Szintén érdekes eredmény, hogy a fordítástudomány és a fordításelmélet terminusok közül a fordítástudomány majdnem kétszer annyi alkalommal fordult elö a hallgatók válaszaiban, mint a fordításelmélet. Összefoglalásként az előadó megállapította, hogy a hallgatók azokat a részeket tartották a leghasznosabbaknak, amelyekben saját kutatási eredményeinek példáit mutatta be, és amelyekhez a gyakorlatban is hasznosítható tanácsokat füzött az elmélet bemutatása után. 